\title{
Invited review: Effects of group housing of dairy calves on behavior, cognition, performance, and health
}

\author{
J. H. C. Costa, M. A. G. von Keyserlingk, and D. M. Weary ${ }^{1}$ \\ Animal Welfare Program, Faculty of Land and Food Systems, The University of British Columbia, 2357 Mall, Vancouver, BC, Canada, V6T $1 Z 4$
}

\begin{abstract}
Standard practice in the dairy industry is to separate the calf and dam immediately after birth and raise calves in individual pens during the milk-feeding period. In nature and in extensive beef systems, the young calf lives in a complex social environment. Social isolation during infancy has been associated with negative effects, including abnormal behavior and developmental problems, in a range of species. Here, we review empirical work on the social development of calves and the effects of social isolation in calves and other species; this evidence indicates that calves reared in isolation have deficient social skills, difficulties in coping with novel situations, as well as specific cognitive deficits. We also review the practices associated with group housing of dairy calves, and discuss problems and suggested solutions, especially related to cross-sucking, competition, aggression, and disease. The studies reviewed indicate that social housing improves solid feed intakes and calf weight gains before and after calves are weaned from milk to solid feed. Evidence regarding the effects of social housing on calf health is mixed, with some studies showing increased risk of disease and other studies showing no difference or even improved health outcomes for grouped calves. We conclude that there is strong and consistent evidence of behavioral and developmental harm associated with individual housing in dairy calves, that social housing improves intakes and weight gains, and that health risks associated with grouping can be mitigated with appropriate management.
\end{abstract}

Key words: social isolation, individual housing, replacement heifers, neonate development

\section{INTRODUCTION}

Infancy is one of the most important periods of development for mammals, with the environment playing a crucial role (see review by Bornstein, 1989). The

Received July 20, 2015.

Accepted December 29, 2015.

${ }^{1}$ Corresponding author: danweary@mail.ubc.ca detrimental effects of maternal separation and social isolation during infancy have been studied in a range of social species, including rodents (Heim et al., 2004), primates (Harlow et al., 1965), and humans (TrollerRenfree et al., 2015). Negative effects of social deprivation early in life have been shown in adulthood, which include impaired maternal care (e.g., Lovic et al., 2011), increased aggression (e.g., Toth et al., 2011), and impaired social recognition (e.g., Lukas et al., 2011).

Most farmed mammals (e.g., sheep, pigs, horses, and beef cattle) are housed with their dam during the milk feeding period, and the young normally also have contact with conspecifics of similar age. Dairy cattle production is the exception; standard practice within the industry is to separate calves from the dam soon after birth and raise calves in individual pens during the milk-feeding period (USDA, 2008; Vasseur et al., 2010). This limited maternal and social contact is in contrast to what occurs under natural conditions (Reinhardt and Reinhardt, 1981).

To our knowledge, no attempt has been made to summarize the available scientific information on the effects of social isolation on calves. This review describes the research to date assessing the role of isolation and social housing on calf development. We begin with a brief account of social development in natural settings when cows rear their young. We then review the literature on cattle and other species describing the effects on neonates of maternal and other types of social deprivation, and where applicable, draw from theories based on the human and laboratory animal literature. Finally, we discuss the group housing literature, describing challenges and successful practices associated with social housing of dairy calves. Where possible, we include recommendations for future research and considerations for application on farms.

\section{SOCIAL DEVELOPMENT IN CALVES}

Shortly before parturition, cows tend to separate themselves from the herd and give birth in a secluded area (Lidfors et al., 1994). Once the calf is born, a series of maternal behaviors are observed, including licking 
of the calf and specific vocalizations (reviewed by von Keyserlingk and Weary, 2007). The dam normally keeps the young hidden in bushes or tall grass for the first few days while she forages nearby (Langbein and Raasch, 2000). The newborn calf is fully dependent on the milk provided by the dam and will nurse approximately 8 to 12 times daily during the first week of life, with each suckling bout lasting approximately $10 \mathrm{~min}$ (e.g., Reinhardt and Reinhardt, 1981; Day et al., 1987; Lidfors, 1996).

After several days, the calf and mother reintegrate into the herd (Bouissou et al., 2001). During the second week of life, the calf starts to increase the distance from the dam, begins interacting with peers, and may form small groups with other calves (Vitale et al., 1986; Sato et al., 1987). These calf groups also interact with older animals, and it has been reported that adolescents and adults without newborn calves will graze close to calf groups (e.g., Sato et al., 1987; Murphey and de Moura Duarte, 1990). This suite of characteristics and behaviors are also observed in other ungulates such as caribou (Rangifer tarandus; Rettie and Messier, 2001) and moose (Alces alces; Bowyer et al., 1999).

Under natural or semi-natural conditions, grazing ruminants select their diets from a wide variety of plants differing in nutritional composition and availability (Provenza and Balph, 1987; Baumont, 2000). Calves that are reared with their dam and other conspecifics start grazing and ruminating at approximately 3 wk of age and graze regularly with the herd at 3 to 6 mo of age (Reinhardt and Reinhardt, 1981; Vitale et al., 1986). The social interactions of young ungulates are associated with learning to recognize suitable diet and habitat, where selection happens through the mimicking or imitation of social companions (i.e., Key and MacIver, 1980; Mirza and Provenza, 1992, 1994). The progression from maternal care to independence is an important period of learning for young foragers (Provenza and Balph, 1987), making social partners important influences on diet selection for young ruminants (Nolte et al., 1990; Provenza et al., 2003).

Social learning allows individuals to learn from the positive or negative effects on another individual (Bandura, 1977; Conte and Paolucci, 2001); this type of learning is thought to be important in the development of feeding behavior in many farmed species (Keeling and Hurnik, 1996; Launchbaugh and Howery, 2005). Naïve dairy heifers show a more rapid onset of grazing when introduced to pasture with experienced social companions (Costa et al., 2016). Social learning theory suggests that the most effective social models are the dam and dominant peers (Bandura, 1977). Herbivores that feed in large mixed-generation groups, like cattle, are able to use social learning to transmit information about suitable food items from experienced to inexperienced foragers (Boyd and Richerson, 1996).

Food neophobia is well known in ruminants (Chapple and Lynch, 1986) and is defined as avoidance and reluctance to taste unfamiliar foods (Cooke et al., 2006). Food neophobia is known to decrease in the presence of companions in lambs (Nolte et al., 1990) and when dairy calves are raised in complex social groups (Costa et al., 2014). In nature, young ruminants must learn how to select and eat appropriate foods (Freeland and Janzen, 1974); social learning enables an inexperienced animal to avoid the inefficiency and risk of testing each novel feed type, because the "trial-and-error" strategy could lead to the ingestion of toxic feed (Galef and Laland, 2005; Nicol, 2006).

In summary, young ruminants naturally form social relationships starting with the dam and then with other individuals, even in the first weeks of life. During the milk-feeding period, the calf relies on social cues from the dam and other conspecifics that influence behavioral development. Given that most dairy calves are separated from their mothers at birth and reared individually [e.g., $77 \%$ in the United States (USDA, 2008); 88\% in Canada (Vasseur et al., 2010); $70 \%$ in Brazil (Hötzel et al., 2014)], numerous questions arise regarding potential negative effects of social isolation on social and feeding behaviors and other aspects of development. In addition to the effects outlined above, the results from several species suggest that social isolation may have important effects on cognitive development, as described below.

\section{EFFECTS OF SOCIAL ISOLATION: EVIDENCE FROM OTHER SPECIES}

There is considerable variation within the literature in what is called "social isolation," ranging from complete isolation for extended periods (e.g., Sackett et al., 1981) to $2 \mathrm{~h}$ daily during the second week of age (Tuchscherer et al., 2006). Social isolation was defined by Gottman (1977) as an absence or low frequency of peer interaction during an extended period. This definition applies to most dairy calves during the milk-feeding period and will be used in this review.

Bowlby (1969) famously described how events during childhood in humans have profound influences on behavior, even as adults. Individuals who experience social isolation or social deprivation during childhood tend to have psychological and behavioral disorders later in life, such as a greater tendency to develop schizophrenia (Rutter, 1979) and to express violent behavior and abnormal emotional responses (Bowlby, 1969). Some 
of these effects are also found when social isolation occurs in adulthood (as reviewed by Cacioppo et al., 2011). There is also evidence for long-term neurological (Heim and Nemeroff, 2001; Shanks and Lightman, 2001), neuroendocrine, and immune alterations from negative events during childhood (as reviewed by Neigh et al., 2009). Social isolation can also be an important risk factor for morbidity and mortality; as reviewed by House et al. (1988), social isolation increases the likelihood of smoking, obesity, sedentary lifestyle, and high blood pressure.

A variety of studies have shown how maternal separation or social deprivation from conspecifics early in life adversely affects brain and behavior development in nonhuman animals [e.g., primates (Harlow et al., 1965); rats (Heim et al., 2004, Haller et al., 2014); mice (Kercmar et al., 2014); pigs (Worobec et al., 1999); voles (Shapiro and Insel, 1990)]. Social isolation in rodents is often associated with increased anxiety-like behavior (as reviewed by Hall, 1998; Fone and Porkees, 2008), and enhanced hypothalamic-pituitary-adrenal axis (HPA) responsiveness to stressors (Serra et al., 2007).

Early social deprivation has been associated with long-term alterations in social behavior of nonhuman animals, such as when adults express impaired maternal care (Lovic et al., 2011), increased aggression (Veenema et al., 2006, 2007; Toth et al., 2011), and impaired social recognition (Lukas et al., 2011). Together, these are labeled as "isolation-induced stress syndrome" in rodents (Valzelli, 1973; Holson et al., 1991). Maternal separation, total or partial, has been associated with long-term alteration in behaviors in nonhuman animals and with changes in emotionality (Kraemer et al., 1991), cognitive functions, physiological and stress coping mechanisms (Fahlke et al., 2000), excessive alcohol consumption (Higley et al., 1991; Fahlke et al., 2000), and associated neuroendocrine and neuronal adaptations (Poletto et al., 2006a,b). Nursery rearing, an example of maternal deprivation, was shown to have a strong detrimental impact on the development of rhesus macaques and has been shown to cause disruptions in social behavior, hyperactivity, and increased sensitivity to stressors (Harlow et al., 1965; Suomi et al., 1971; Suomi, 1991). Rhesus macaque infants reared in this manner had increased cortisol responses to social situations during adulthood (Fahlke et al., 2000) and showed signs of depression (Kraemer et al., 1991). The conclusion from this body of work is that social experience with the mother and conspecifics is required for normal development in social species (reviewed by Parker and Maestripieri, 2011).

Relatively little work on social isolation has focused on farm animals, but the limited studies available align with the rodent and primate studies cited above. For example, piglets weaned at younger ages were slower to habituate to their new environment and exhibited more escape behavior, less interaction with neighboring pigs, and less time feeding than pigs weaned at an older age (Worobec et al., 1999; Davis et al., 2006). Social isolation also increases cortisol responses to stress in pigs (Kanitz et al., 2009). Premature separation from mothers has detrimental effects, even in precocial species such as sheep. For instance, artificial rearing of lambs, where animals are fed milk by humans instead of conspecifics, has been associated with negative effects on behavior as well as endocrine and immune levels (i.e., Napolitano et al., 1995, 2002). Lambs separated from the dam showed reduced frequency of vocalization, were slower to initiate movements, and displayed an increased cortisol response during an open-field test compared with animals raised in a complex social environment (Moberg and Wood, 1982; Napolitano et al., 2002; also see review by Napolitano et al., 2008). In summary, research on several different species has shown that social isolation is associated with abnormal behavior and developmental problems. It would thus seem reasonable to predict similar effects in dairy calves.

\section{EFFECTS OF SOCIAL ISOLATION ON THE DAIRY CALF}

Dairy calves that have been separated from the dam will begin interacting with other calves, when given the opportunity, as early as $2 \mathrm{~d}$ after birth (Duve and Jensen, 2012). Socially housed dairy calves spend, on average, only about $2 \%$ of their time engaged in social contact during the first $8 \mathrm{wk}$ of life (Chua et al., 2002), but calves appear to be highly motivated to initiate this contact. For example, calves work harder to gain access to full social contact with a calf than to have limited social contact across a barrier (Holm et al., 2002). Young dairy calves housed in groups showed a preference for a known peer in contrast to an unfamiliar calf during a choice test (Færevik et al., 2006; Duve and Jensen, 2011), providing evidence that they form social connections from a young age. Other work has shown that social relationships that were formed early in life were long lasting (Raussi et al., 2010).

Given that calves are typically provided little or no social contact on dairy farms, and the wealth of information on other species showing detrimental effects of isolation, exploring the effects of social isolation in dairy calves would seem to be important. The following section reviews research examining the effects of early social deprivation on behavioral problems, coping with 
novelty, and cognitive development. We also discuss evidence that social support and social buffering may mitigate some of the negative effects of stressful management practices on calves.

\section{Behavior Problems}

A growing body of work has examined the relationship between the social environment and behavior in calves (summarized in Table 1). This evidence suggests that socially reared calves are less fearful (reviewed by Bøe and Færevik, 2003) and more dominant when mixed in groups later in life (Veissier et al., 1994) compared with calves that have been reared in isolation. Several factors play a role in social behavior development, such as age of first contact with conspecifics and level of contact. For instance, calves allowed full social contact with another calf, either from birth or from 3 wk of age, established a stronger bond compared with calves raised with only visual or auditory contact with other calves (Duve and Jensen, 2011). Calves housed individually or with only limited contact were more fearful than pair-housed calves (Jensen and Larsen, 2014). Collectively, this evidence suggests that full social contact with peers from an early age is important for the calf.

\section{Social Support}

Social support is defined as the beneficial effects of the presence of a conspecific, irrespective of whether the individual is being challenged or not (Cohen and Wills, 1985). Social support is known to have beneficial effects on humans (for reviews see Kikusui et al., 2006; Hennessy et al., 2009). Social buffering is the ability of social partners to decrease the effect of stressors during a challenge (Cohen and Wills, 1985) and is the aspect of social support that has been studied in animals. Social buffering has been demonstrated in humans (Thorsteinsson et al., 1998), rats (Kiyokawa et al., 2014a), guinea pigs (Hennessy et al., 2000), pigs (Reimert et al., 2014), and other farm animals (Rault, 2012). For example, the work on rats has shown a decreased response to stressors in the presence of others (Hennessy et al., 2000; Kiyokawa et al., 2014a), especially familiar conspecifics (Kiyokawa et al., 2014b).

In cattle, the presence of conspecifics is known to reduce behavioral reactions to social separation (Boissy and Le Neindre, 1997; Piller et al., 1999). For example, calves vocalize less in a novel arena when in companionship with familiar calves compared with when they are placed with unfamiliar calves (Færevik et al., 2006). There is also some evidence of social buffering in calves in response to a nonsocial stressor; individually housed

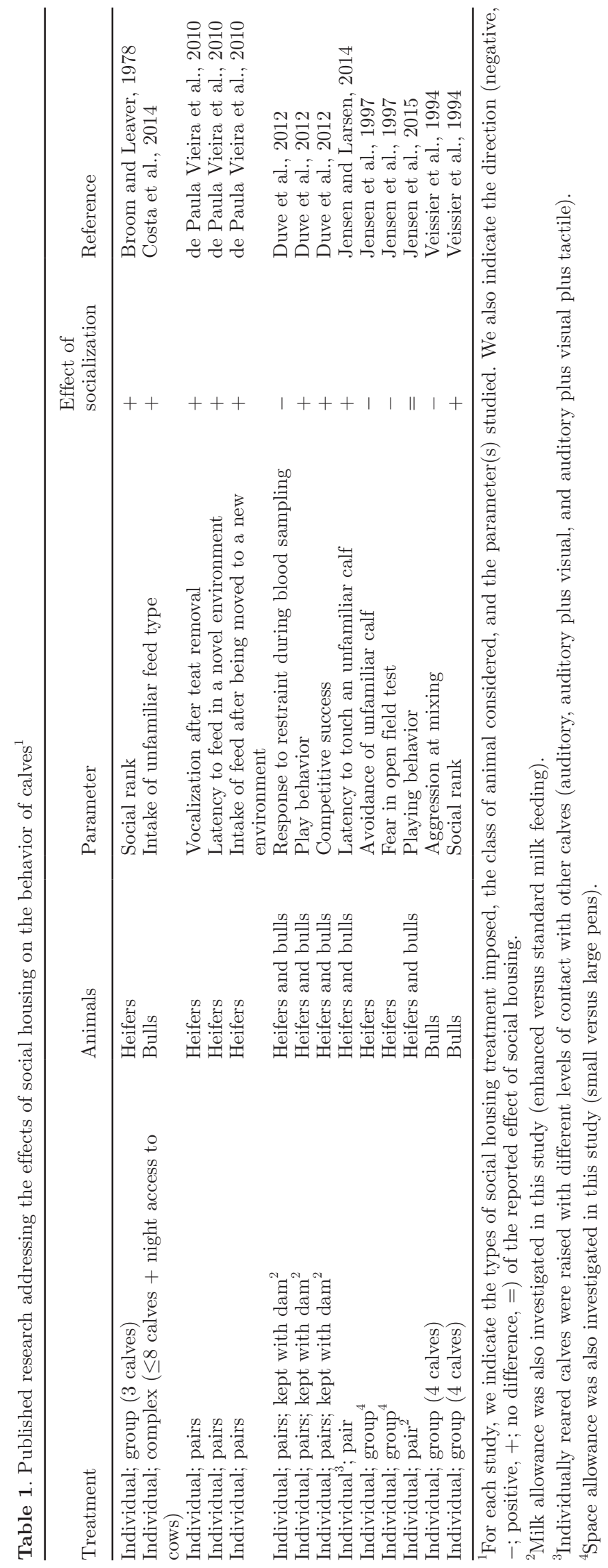


calves show a stronger vocal response to weaning from milk compared with paired calves (de Paula Vieira et al., 2010). Further work is needed to assess the effects of social support on responses to other husbandry procedures such as castration and dehorning. Also, future research should investigate how the type and strength of social relationships affect the magnitude of any social buffering.

\section{Coping with Novelty}

Farm animals, including dairy cattle, are often exposed to novel events, such as changes in diet, changes in pen location, regrouping with new social partners, and new milking procedures. Individually reared calves show greater reactivity to environmental novelty compared with socially reared animals. Veissier et al. (1997) showed that isolation of calves promoted reactiveness to startling stimuli and development of self-directed oral behaviors. Calves housed individually for the first 3 mo of life were more reactive to environmental and social novelty than group-housed animals when tested at $90 \mathrm{~d}$ of age (Jensen et al., 1997).

In contrast, early social contact reduces behavioral and physiological reactivity to environmental novelty. Calves provided social contact showed decreased responses to restraint, increased play during the milk feeding phase, and increased competitive success after weaning (Duve et al., 2012), as well as lower adrenocortical reactivity to stress (Creel and Albright, 1988; Raussi et al., 2003). Calves raised in pairs or in small groups of calves showed lower heart rates when placed in a pen with an unfamiliar calf (Jensen et al., 1997) and were less fearful and more willing to approach unfamiliar calves when mixed after weaning (de Paula Vieira et al., 2012a). Socially reared calves were also less neophobic toward a new food item than calves reared individually (Costa et al., 2014).

\section{Cognition}

Social isolation early in life can impair cognition in rodents and other species (Jones et al., 1991; Fone and Porkess, 2008). Socially isolated rodents showed deficits in reversal learning (Jones et al., 1991), a method often used to assess behavioral flexibility in animals (Fone and Porkess, 2008). A recent study examined reversal learning in pair-housed and individually housed calves and found that individually housed calves made more mistakes during the reversal-learning phase, indicating impaired behavioral flexibility (Gaillard et al., 2014). A follow-up study, using a color discrimination training task, showed that calves housed with social companions from an early age, either in a complex social environ- ment (with the presence of their dam and other cows and calves) or simply pair-housed, performed better in reversal learning than did individually raised calves (Meagher et al., 2015). In the latter study, the majority of individually housed calves did not learn the reversal task even when provided twice as many sessions as required by the average socially housed calf. Similar results have been reported in rodents, and these studies indicate that the cognitive deficit is associated with decreased brain development and plasticity (e.g., Schrijver and Würbel, 2001; Fowler et al., 2002; Schrijver et al. 2002; Lipkind et al., 2002). In rodents, it is well established that the prefrontal cortex is responsible for behavioral control, decision-making, and inhibition of behavior (Dalley et al., 2004). These controls are essential for success in reversal learning.

We conclude that calves raised in isolation exhibit deficient social skills, difficulties in coping with novel situations, and poor learning abilities, all of which may reduce the animal's ability to adjust to variable environments on the dairy farm. Behavioral flexibility is widely believed to depend on exposure to a variable environment in early life (Sackett, 1970). Future studies should investigate the length of the critical periods for social contact that avoid the deleterious effects on cognition and behavioral flexibility. Further work is required to test the effects of providing more complex environments (e.g., more naturalistic environments such as access to the outdoors, increased human contact, or access to interactive toys), with and without access to social conspecifics. Work is also required to better understand the longer-term effects of social deprivation on cognitive impairment, and whether these effects can be reversed.

\section{Longer-Term Effects}

Most of the work to date in dairy calves has focused on the effects of social isolation during the milk-feeding period, the weaning period, and the days immediately following weaning. The lack of work on longer-term effects is likely due to the time required and the challenges associated with maintaining adequate controls. Work to date suggests that negative effects can persist. For example, studies by Le Neindre (1989a, b) found that calves reared with a foster cow showed more pronounced maternal behavior and more locomotion and exploration during isolation tests years later. Another study reported that dam-reared calves transitioned better into the lactating herd, suggesting that social housing of calves may enhance social skills that are useful later in life (Wagner et al., 2012). In a complementary study, long-term effects of dam rearing were tested using an isolation challenge when cows were 2.5 
yr old. Cows that had experienced 12 wk of contact with the dam showed greater behavioral activity during the isolation test compared with cows that had been individually raised (Wagner et al., 2014). However, these studies should be considered preliminary due to the lack of controls during the growing phase and the small sample sizes (as few as 5 animals per treatment). Further work should assess the longer-term effects of social versus individual rearing on behavioral flexibility as adults, and whether the detrimental effects of social isolation can be reversed through enriched environments or other means.

We conclude that rearing dairy calves individually has negative effects on calf development. Housing systems for newborn and milk-fed dairy calves should meet their thermal, physical, psychological, and behavioral needs (Stull and Reynolds, 2008); the common practice of individual rearing violates at least two of these criteria (i.e., psychological and behavioral). However, if dairy farms are to rear milk-fed calves in groups, understanding the practical benefits and constraints of social housing is essential. We turn to these more practical issues in the following section.

\section{GROUP HOUSING OF DAIRY CALVES: CHALLENGES AND SOLUTIONS}

One benefit of housing calves in groups includes reduced labor requirement per head (Broom and Leaver, 1978). One recent study reported that "reducing labor" and "saving time" were among the main reasons that farmers provided for group-housing dairy calves (Hötzel et al., 2014). The development of automated feeding systems for calves has accelerated adoption of group housing of dairy calves, particularly for larger dairy farms (Kung et al., 1997). There is also increased awareness of animal welfare by both dairy producers and the public, and one important welfare concern is the social isolation of calves (Boogaard et al., 2010; Ventura et al., 2013). Furthermore, group housing has been associated with increased ADG in dairy calves (Bernal-Rigoli et al., 2012; Jensen et al., 2015). A growing body of work has also examined the relationship between the social environment and other performance measures, as described below. Collectively, these results support the idea that social housing positively influences performance of dairy calves.

\section{Improved Feed Intakes and Weight Gains in Socially Reared Calves}

Group housing of calves is associated with increased BW gains compared with individually housing, likely due to increased DMI, as summarized in Table 2. Contact with the dam or other older animals within the first few weeks of life is known to stimulate young ungulates to start sampling solid feed at a younger age (Key and MacIver, 1980; Nolte et al., 1990) and to eat more, especially in the preweaning phase. Warnick et al. (1977) reported that social housing increased concentrate intake during the preweaning period, resulting in greater weight gains after weaning. Those authors speculated that the benefits were due to social learning by group-housed calves. Also, the stimulus of another animal eating, approaching, and manipulating the feed may increase attention toward the feed without any learning per se (Galef, 1981). This process of "social facilitation" was defined by Galef (1988) as "the initiation of a particular response while observing others engaged in that behavior," and several authors have suggested that social facilitation may be important in cattle (e.g., Ralphs et al., 1994; de Paula Vieira et al., 2012b; Costa et al., 2015). Regardless of the mechanism, both social facilitation and social learning may result in socially housed calves showing higher intakes of solid feed and improved BW gains compared with individually housed calves.

Further work is required to understand the mechanism of social influence on the feeding behavior of dairy calves. We suggest the use of a 2-action and control experimental design, where social learning is tested by exposing naïve animals to different demonstrators trained on 1 of 2 feeding patterns and a control with no demonstrator (Whiten and Mesoudi, 2008). This design would help to disentangle social facilitation from social learning. Also, calves housed with the dam or other older animals may have different influences compared with those only provided contact with conspecifics of the same age. Little is known about how the mother and other adults function as social models on early preferences for solid feed. The increased solid feed intake in socially reared calves may also occur due to increased attention to the feed given that other animals are also in contact with the feed. Thus, exploring alternative methods that draw attention to the feed may be effective at increasing intakes. For example, mechanically shaking or simply changing the feed more frequently may increase attention and ultimately increase intakes. In piglets, it has been shown that a "play feeder" (an open trough with 3 protrusions to stimulate exploration) can increase creep feed intake (Kuller et al., 2010). To our knowledge, this approach has not been applied in calves.

One study found that grass intake and time spent grazing were greater for grouped calves than for individual calves (Phillips, 2004) and another found that 
Table 2. Published research on the effects of social housing on feeding behavior and performance of calves ${ }^{1}$

\begin{tabular}{|c|c|c|c|c|}
\hline Treatment & Animals & Parameter & $\begin{array}{l}\text { Effect of } \\
\text { socialization }\end{array}$ & Reference \\
\hline Individual; group (3 calves) & Bulls & BW & + & Andrighetto et al., 1999 \\
\hline Individual; group ( 6 calves) & Heifers and bulls & Solid feed intake & + & Babu et al., 2004 \\
\hline Individual; group ( 6 calves) & Heifers and bulls & Solid feed intake & $=$ & Babu et al., 2009 \\
\hline Individual; group ( 3 or 4 calves) ${ }^{2}$ & Bulls & DMI & + & Bernal-Rigoli et al., 2012 \\
\hline Individual; group ( 3 or 4 calves) ${ }^{2}$ & Bulls & BW & + & Bernal-Rigoli et al., 2012 \\
\hline Individual; pairs & Heifers and bulls & ADG & $=$ & Chua et al., 2002 \\
\hline Individual; pairs & Bulls & Solid feed intake & + & Costa et al., 2015a \\
\hline Individual; pairs & Bulls & $\mathrm{ADG}$ & + & Costa et al., 2015a \\
\hline Individual; pairs & Heifers & Concentrate intake & + & de Paula Vieira et al., 2010 \\
\hline Individual; pairs & Heifers & $\mathrm{ADG}$ & $=$ & de Paula Vieira et al., 2010 \\
\hline Individual; pairs $^{3}$ & Bulls & ADG & $=$ & Hänninen et al., 2005 \\
\hline Individual; group (4 calves) ${ }^{4}$ & Bulls & Solid feed intake & + & Hepola et al., 2006 \\
\hline Individual; group (3 calves) & Heifers & Grass intake & + & Phillips, 2004 \\
\hline Individual; group (3 calves) & Heifers & BW gain & $=$ & Phillips, 2004 \\
\hline Individual; group (3 calves) & Heifers and bulls & Final BW & + & Richard et al., 1988 \\
\hline Individual; group (3 calves) & Heifers and bulls & Concentrate intake & $=$ & Richard et al., 1988 \\
\hline Individual; group (3 calves) & Heifers and bulls & Solid feed intake & + & Tapki, 2007 \\
\hline Individual; group (3 calves) & Heifers and bulls & ADG & + & Tapki, 2007 \\
\hline Individual; group ( 5 calves) & Bulls & Solid feed & $=$ & Terré et al., 2006 \\
\hline Individual; group ( 5 calves) & Bulls & BW & $=$ & Terré et al., 2006 \\
\hline Individual; group (6 calves) & Heifers and bulls & Solid feed intake & $=$ & Warnick et al., 1977 \\
\hline Individual; group ( 6 calves) & Heifers and bulls & $\mathrm{ADG}$ & + & Warnick et al., 1977 \\
\hline Individual; group ( 4 calves) & Bulls & BW & + & Xiccato et al., 2002 \\
\hline Individual; group (4 calves) & Bulls & ADG & + & Xiccato et al., 2002 \\
\hline
\end{tabular}

${ }^{1}$ For each study, we indicate the types of social housing treatment imposed, the class of animal considered, and the parameter(s) studied. We also indicate the direction (positive, + ; no difference, $=$ ) of the reported effect of social housing.

${ }^{2}$ Milk feeding method was also investigated in this study (bottle vs. bucket feeding).

${ }^{3}$ Flooring type was also investigated in this study (concrete vs. rubber mat).

${ }^{4}$ Enviromental temperature was also investigated in this study (warm vs. cold buildings).

${ }^{5}$ Milk allowance was also investigated in this study (enhanced vs. standard milk feeding).

raising calves in groups increased concentrate consumption and the early onset of rumination compared with individual rearing (Babu et al., 2003, 2004). BernalRigoli et al. (2012) found that DMI was greater for group housed versus individually housed calves after 41 d of age, resulting in greater BW gains for group-housed calves. Similarly, pair housing of dairy calves has been associated with increased solid feed intake (Jensen et al., 2015). One study found that calves paired at birth or at 3 wk of age consumed more solids than did individually housed calves (Tapki, 2007). Most recently, it was shown that pair housing of calves starting in the first week of life increased calf feed intake and weight gains compared with individual housing and pairing calves at 6 wk of age (Costa et al., 2015). Calves that were group housed early in life, in addition to having increased solid feed intakes, also show reduced behavioral responses to mixing and weaning (Chua et al., 2002; de Paula Vieira et al., 2012a,b).
Calves reared in groups continue to benefit from higher concentrate intakes than calves previously reared individually, even after all calves are mixed in group pens (de Paula Vieira et al., 2010). Such effects that persist beyond the period of individual housing might be due to the better learning abilities of socially housed calves described above, allowing them to learn more rapidly where and how to use new feeders. Duve et al. (2012) found that group-housed calves were faster at locating feed and spent more time eating concentrates in competitive situations than did calves that had been individually housed; these findings are consistent with the interpretation that intake differences persisting beyond the period of individual rearing are due in part to cognitive deficits. In addition, preweaning intake of solid feed helps to improve the transition from milk to solid feed at weaning (reviewed by Weary et al., 2009), such that calves that do not achieve adequate solid feed intakes before weaning experience poor growth and in- 
creased distress during weaning (de Paula Vieira et al., 2008; de Passillé et al., 2011).

Bull calves that were reared in groups also gained weight more rapidly than individually housed calves (Andrighetto et al., 1999; Xiccato et al., 2002). Other work has shown the advantages of early gains during the milk-feeding period on the later weight gains of older heifers (Bond et al., 2015). Early gains also have positive effects on the onset of puberty and milk production in the first and later lactations (Moallem et al., 2010; Soberon et al., 2012). A similar line of research has shown that Holstein bull calves reach puberty earlier and have larger testicular mass when offered a high plane of nutrition early in life (Dance et al., 2015). Thus, early growth achieved in the first weeks of life can have profound effects on production and reproduction later in life.

The social environment can have profound influences on total food intake, diet, and persistence of solid feed intake of calves. As illustrated in Table 2, provision of social companions increased the intake of solids, increased performance (BW or ADG), or both, in 8 of 11 of trials. The other 3 trials failed to detect differences between individually housed and group-housed calves. No study has reported decreased performance in group housing. However, several concerns hinder the adoption of group housing on dairy farms, including cross-sucking, aggression, and transmission of disease (Quigley, 1997; Pempek et al., 2013; Hötzel et al., 2014). These concerns, and methods of addressing them, are reviewed below.

\section{Cross-Sucking}

Cross-sucking is defined as the suckling of one calf directed to the body of another (Jensen, 2003); it is considered a management problem and potentially associated with udder deformations, mastitis, and milk loss (Lidfors and Isberg, 2003). Some studies have reported high levels of cross-sucking in group-housed calves (e.g., Lidfors and Isberg, 2003), but other studies have reported little or none (e.g., Chua et al., 2002; Mattiello et al., 2002), suggesting that the problem can be managed.

One important aspect is the ability to engage in natural suckling behavior. When calves are raised naturally with the dam (Margerison et al., 2003) or with a nurse cow (Krohn et al., 1999), cross-sucking is rare. Several experiments (see review by Jensen, 2003) have demonstrated that feeding milk through a teat instead of a bucket, allowing calves to access milk for many hours of the day instead of just 1 or 2 feedings, and providing a dry teat for calves to suck upon can reduce cross-sucking (Veissier et al., 2002; Lidfors and Isberg, 2003). Calves are highly motivated to suck but motivation for this behavior is closely associated with motivation to drink milk (de Passillé, 2001). Teat feeders and enhanced milk-feeding programs minimize the incidence of cross-sucking by allowing calves to express their natural behavior (de Passillé et al., 2010). Recent studies on calves fed milk via automatic feeders have reported some cross-sucking, especially around weaning (e.g., Nielsen et al., 2008; de Passillé et al., 2011). More gradual weaning procedures reduce cross-sucking in calves (Nielsen et al., 2008), and calves better established on solid feed and with better access to high quality feed are less likely to engage in cross-sucking (Keil and Langhans, 2001).

Although individual housing prevents cross-sucking, individually housed calves engage in other forms of abnormal oral behaviors, including excessive licking of their own bodies and walls and fixtures of the environment (Bokkers and Koene, 2001). Those authors and others (Veissier et al., 1997; Jensen, 2003) have argued that expression of abnormal oral behaviors is likely caused by poor milk-feeding practices (e.g., low milk allowance, bucket feeding, abrupt weaning). When these practices are corrected, abnormal oral behaviors will be rare.

\section{Competition and Aggression}

Competition and aggression can be prevented by social isolation. In early life, competition and aggression are normally associated with feeding (Herrmann and Knierim, 1999). For calves reared in groups fed from a single automatic milk feeder, $89 \%$ of aggressive events happened around the feeder (Herrmann and Knierim, 1999). Not surprisingly, aggression was intensified when calves were fed restricted milk allowances; higher competition at the milk teat can also reduce feeding time and milk intake (von Keyserlingk et al., 2004).

Some management strategies to mitigate competition during milk feeding have been studied. Providing more teats (ideally at least one teat per calf) reduces competition (von Keyserlingk et al., 2004). Automated feeders often use much higher ratios of calves to teats, but reducing the ratio helps to reduce competition. For example, one study found that calves in groups of 24 animals with one teat had increased levels of disturbance when feeding compared with groups of 12 calves (Jensen, 2004). The placement of barriers between the teats also reduces competition, especially when long barriers separate calves' heads and shoulders (Jensen et al., 2008). Offering milk in fewer and larger portions can lower competition for access to teats (Jensen, 
2004), likely because the larger meals are more effective at satiating the calves and thus reduce nonnutritive sucking at the teat (de Paula Vieira et al., 2008). Fewer, larger meals are especially appropriate for older calves, as calves will naturally consume larger and fewer meals per day (Jensen, 2009).

Aggressive behavior also can be reduced by maintaining stable groups. Calves kept in stable groups have fewer aggressive interactions during feeding than regrouped animals (Mounier et al., 2006). Given that it can be difficult to maintain stable groups after weaning, limiting regrouping to the mixing of 2 previously stable groups results in fewer aggressive and more positive social interactions of weaned dairy calves compared with other mixing options (Færevik et al., 2007). Homogenizing groups of calves by age also decreases competition and increases performance (Færevik et al., 2010). In summary, these results suggest that competition can be mitigated by providing enough milk and enough feeding stations, by designing and placing these stations effectively, and by maintaining stable social groups where possible.

\section{Health}

Calf morbidity and mortality are important indicators of herd health status (Ortiz-Pelaez et al., 2008). Calf mortality rates are often high: a study of large farms in Korea reported a mortality rate of $10.7 \%$ during the first year of life (Hur et al., 2013), a UK survey reported a mortality rate of $14.5 \%$ from birth to first calving (Brickell et al., 2009), and in France mortality rates averaged 4.4 and $3.2 \%$ for 3 -d- to 1-mo-old calves and 1- to 6-mo-old calves, respectively (Raboisson et al., 2013). Yearly mortality of heifers in the United States has been reported to be 6.9 and $7.8 \%$ on calf ranches (Walker et al., 2012) and dairy farms (USDA, 2008), respectively .

Enteric and respiratory diseases can be spread through horizontal calf-calf transmission, especially fecal-oral and nose-nose contact, behaviors that can be minimized by individual housing (Steenkamer, 1982; Maatje et al., 1993; McGuirk, 2008). Individual pens may also facilitate monitoring, and thus result in better treatment of disease (Kung et al., 1997). Despite these mechanisms, there is little evidence of a consistent relationship between individual housing and calf health. Some studies (e.g., Webster et al., 1985; Gulliksen et al., 2009) have indeed reported more health problems in group-reared calves, but other empirical studies have found no advantage of individual housing compared with small groups (e.g., Waltner-Toews et al., 1986a,b; Perez et al., 1990; Johnson et al., 2011). As reviewed below, different factors including the amount of milk fed, bedding management, and group size can affect disease risk and should be considered in any comparison between systems.

Early work (Warnick et al., 1977) found that raising calves in groups resulted in higher treatment rates compared with individually housed calves. Another early study reported that chronic and acute respiratory diseases and diarrhea occurred more frequently in group-housed veal calves (Maatje et al., 1993) but this comparison was confounded by differences in milk-feeding methods between grouped (computer-controlled) and individual (bucket feeding twice per day) calves.

Group size can play a role in the health of grouphoused calves. One study on commercial farms in Sweden reported that calves housed in pens of 8 to 12 calves had a higher incidence of respiratory illness than calves housed in smaller groups, but no differences in diarrhea were observed between these treatments (Svensson and Liberg, 2006). Another study found that severe cases of diarrhea were more common in large groups (Svensson et al., 2003). A US study (Losinger and Heinrichs, 1997) found that raising calves in groups with more than 7 calves was associated with a higher mortality, but found no differences between farms with individually housed calves or groups of 6 or fewer. Another study found no difference in disease incidence when comparing groups of 2,4 , and 8 calves (Abdelfattah et al., 2013). Higher morbidity and mortality in large groups of calves may be due to difficulty in detecting, examining, and treating sick calves, resulting in delayed treatments (Steenkamer, 1982; van Putten, 1982).

Another factor that influences disease risk in grouphoused calves is the method of grouping. Pedersen et al. (2009) reported that groups in which new calves were continuously introduced and removed (i.e., dynamic groups) had lower daily gains and a higher incidence of disease than did stable groups (e.g., using all-in-allout management). The aim of all-in-all-out systems is to prevent the spread of infections between groups of animals raised in the same unit, allowing for cleaning and disinfection between groups of animals. In fattening pigs and broilers, all-in-all-out systems reduce the occurrence of infectious disease (i.e., Wierup, 2000).

Some studies found no difference in the incidence of respiratory disorders (Hanekamp et al., 1994) and other health issues between individually reared calves and calves reared in groups (Hänninen et al., 2003). Work on veal calves has shown that contagious diseases including Escherichia coli O157 (Rugbjerg et al., 2003), Salmonella (Losinger et al., 1995), and Cryptosporidium parvum (Mohammed et al., 1999) were not associated with group housing. 
Some work has also reported improved health in grouped calves. For example, Hänninen et al. (2003) found that the incidence of diarrhea was lower in group-housed calves compared with individually housed calves. Babu et al. (2009) also found that diarrhea and respiratory disease were less common in socially housed calves compared with those individually raised.

In summary, diarrhea and respiratory illness, the most common diseases in young calves, are not consistently associated with group housing. Disease transmission is complex and many other management practices influence the risk of these diseases, including methods of milk feeding, hygiene, ventilation, colostrum practices, diet, and health monitoring. We suggest that controlling these variables is a more effective method of minimizing health problems in dairy calves. The results above indicate that calves can be grouped in good health if housing is properly managed, but more research is required on factors that improve the health of grouped calves. In particular, we urge long-term studies that focus on factors including ventilation, age of contact, feeding program, and preventive measures. Additionally, the effect of group housing on the future health status of adult animals is worthy of investigation.

\section{CONCLUSIONS}

The detrimental effects of social isolation are now recognized in a range of species, and newer work on dairy calves has shown that animals reared in isolation show deficient social skills, difficulties in coping with novel situations, and poorer learning abilities. Social housing for calves also improves solid feed intakes preweaning and helps improve weight gains before and after calves are weaned from milk to solid feed. We encourage future work on the persistence of the negative effects of social isolation on cognition and behavioral flexibility, and on the critical periods during which these effects may be reversed. We also urge new studies on the longer-term effects of social rearing on heifer and cow behavior, health and production. Together, this will lead to a better understanding of housing and management conditions required for group housing to succeed.

\section{ACKNOWLEDGMENTS}

We thank the two anonymous reviewers, Heather W. Neave (UBC Animal Welfare Program), Jennifer L. Black (UBC Food Nutrition and Health Program), Andréia de Paula Vieira (Federal University of the Parana, Curitiba Brazil), and Maria José Hötzel (Federal University of Santa Catarina, Florionopolis, Brazil) for their input and comments on previous drafts of this manuscript. Joao H. C. Costa received a scholarship from $\mathrm{CNPq}$ (The Brazilian National Council for Scientific and Technological Development). Much of our research on this topic was funded by a Discovery Grant to D. M. Weary from Canada's Natural Sciences and Engineering Research Council (NSERC; Ottawa, ON, Canada). Our research group is funded by NSERC's Industrial Research Chair program, with industry contributions from the Dairy Farmers of Canada (Ottawa, ON, Canada), British Columbia Dairy Association (Burnaby, BC Canada), Westgen Endowment Fund (Milner, BC, Canada), Intervet Canada Corporation (Kirkland, QC, Canada), Novus International Inc. (Oakville, ON, Canada), Zoetis (Kirkland, QC, Canada), BC Cattle Industry Development Fund (Kamloops, BC, Canada), Alberta Milk (Edmonton, AB, Canada), Valacta (St. Anne-de-Bellevue, QC, Canada), and CanWest DHI (Guelph, ON, Canada).

\section{REFERENCES}

Abdelfattah, E. M., M. M. Schutz, D. C. Lay, J. N. Marchant-Forde, and S. D. Eicher. 2013. Effect of group size on behavior, health, production, and welfare of veal calves. J. Anim. Sci. 91:5455-5465.

Andrighetto, I., F. Gottardo, D. Andreoli, and G. Cozzi. 1999. Effect of type of housing on veal calf growth performance, behaviour and meat quality. Livest. Prod. Sci. 57:137-145.

Babu, L. K., H. N. Pandey, R. C. Patra, and A. Sahoo. 2009. Hematobiochemical changes, disease incidence and live weight gain in individual versus group reared calves fed on different levels of milk and skim milk. Anim. Sci. J. 80:149-156.

Babu, L. K., H. N. Pandey, and A. Sahoo. 2003. Effect of individual versus group rearing and feeding of different levels of milk and skim milk on nutrient utilization in crossbred calves. Asian-australas. J. Anim. Sci. 16:1455-1459.

Babu, L. K., H. N. Pandey, and A. Sahoo. 2004. Effect of individual versus group rearing on ethological and physiological response of cross-bred calves. Appl. Anim. Behav. Sci. 87:177-191.

Bandura, A. 1977. Self-efficacy: Toward a unifying theory of behavioral change. Psychol. Rev. 84:191-215.

Baumont, R. 2000. How forage characteristics influence behaviour and intake in small ruminants: A review. Livest. Prod. Sci. 64:15-28.

Bernal-Rigoli, J. C., J. D. Allen, J. A. Marchello, S. P. Cuneo, S. R. Garcia, G. Xie, L. W. Hall, C. D. Burrows, and G. C. Duff. 2012. Effects of housing and feeding systems on performance of neonatal Holstein bull calves. J. Anim. Sci. 90:2818-2825.

Bøe, K. E., and G. Færevik. 2003. Grouping and social preferences in calves, heifers and cows. Appl. Anim. Behav. Sci. 80:175-190.

Boissy, A., and P. Le Neindre. 1997. Behavioral, cardiac and cortisol responses to brief peer separation and reunion in cattle. Physiol. Behav. 61:693-699.

Bokkers, E. A. M., and P. Koene. 2001. Activity, oral behaviour and slaughter data as welfare indicators in veal calves: A comparison of three housing systems. Appl. Anim. Behav. Sci. 75:1-15.

Bond, G. B., M. A. G. von Keyserlingk, N. Chapinal, E. A. Pajor, and D. M. Weary. 2015. Among farm variation in heifer BW gains. Animal 9:1884-1887.

Boogaard, B. K., B. B. Bock, S. J. Oosting, and E. Krogh. 2010. Visiting a farm: An exploratory study of the social construction of animal farming in Norway and the Netherlands based on sensory perception. Int. J. Sociol. Agric. Food 17:24-50.

Bornstein, R. F. 1989. Exposure and affect: Overview and meta-analysis of research, 1968-1987. Psychol. Bull. 106:265-289. 
Bouissou, M. F., A. Boissy, P. Neindre, and I. Veissier. 2001. The social behaviour of cattle. Pages 113-135 in Social Behaviour in Farm Animals. L. J. Keeling and H. W. Gonyou, ed. CABI Publishing, Wallingford, UK.

Bowlby, J. 1969. Attachment and Loss. Vol, 1. Hogarth, London, UK. Bowyer, R. T., V. Van Ballenberghe, J. G. Kie, and J. A. K. Maier. 1999. Birth-site selection by Alaskan moose: maternal strategies for coping with a risky environment. J. Mammal. 80:1070-1083.

Boyd, R., and P. J. Richerson. 1996. Why culture is common, but cultural evolution is rare. Page 77-94 in Proc. British Acad. Symp., Oxford Univ., Oxford, UK.

Brickell, J. S., M. M. McGowan, D. U. Pfeiffer, and D. C. Wathes. 2009. Mortality in Holstein-Friesian calves and replacement heifers, in relation to body weight and IGF-I concentration, on 19 farms in England. Animal 3:1175-1182.

Broom, D. M., and J. D. Leaver. 1978. Effects of group rearing or partial isolation on later social behaviour of calves. Anim. Behav. $26: 1255-1263$

Cacioppo, J. T., L. C. Hawkley, G. J. Norman, and G. G. Berntson. 2011. Social isolation. Ann. N. Y. Acad. Sci. 1231:17-22.

Chapple, R. S., and J. J. Lynch. 1986. Behavioural factors modifying acceptance of supplementary foods by sheep. Res. Dev. Agric. $3: 113-120$.

Chua, B., E. Coenen, J. Van Delen, and D. M. Weary. 2002. Effects of pair versus individual housing on the behavior and performance of dairy calves. J. Dairy Sci. 85:360-364.

Cohen, S., and T. A. Wills. 1985. Stress, social support, and the buffering hypothesis. Psychol. Bull. 98:310-357.

Conte, R., and M. Paolucci. 2001. Intelligent social learning. J. Artif. Soc. Soc. Simul. 4:U61-U82.

Cooke, L., S. Carnell, and J. Wardle. 2006. Food neophobia and mealtime food consumption in 4-5 year old children. Int. J. Behav. Nutr. Phys. Act. 3:14.

Costa, J. H. C., W. G. Costa, D. M. Weary, L. C. P. Machado Filho, and M. A. G. von Keyserlingk. 2016. Dairy heifers benefit from the presence of an experienced companion when learning how to graze. J. Dairy Sci. 99:562-568. http://dx.doi.org/10.3168/jds.2015-9387.

Costa, J. H. C., R. R. Daros, M. A. G. von Keyserlingk, and D. M. Weary. 2014. Complex social housing reduces food neophobia in dairy calves. J. Dairy Sci. 97:7804-7810.

Costa, J. H. C., R. K. Meagher, M. A. G. von Keyserlingk, and D. M. Weary. 2015. Early pair housing increases solid feed intake and weight gains in dairy calves. J. Dairy Sci. 98:6381-6386.

Creel, S. R., and J. L. Albright. 1988. The effects of neonatal social isolation on the behavior and endocrine function of Holstein calves. Appl. Anim. Behav. Sci. 21:293-306.

Dalley, J. W., D. E. Theobald, P. Bouger, Y. Chudasama, R. N. Cardinal, and T. W. Robbins. 2004. Cortical cholinergic function and deficits in visual attentional performance in rats following 192 IgG-saporin-induced lesions of the medial prefrontal cortex. Cereb. Cortex 14:922-932.

Dance, A., J. Thundathil, R. Wilde, P. Blondin, and J. Kastelic. 2015. Enhanced early-life nutrition promotes hormone production and reproductive development in Holstein bulls. J. Dairy Sci. 98:987998.

Davis, M. E., S. C. Sears, J. K. Apple, C. V. Maxwell, and Z. B. Johnson. 2006. Effect of weaning age and commingling after the nursery phase of pigs in a wean-to-finish facility on growth, humoral and behavioral indicators of well-being. J. Anim. Sci. 84:743-756.

Day, M. L., K. Imakawa, A. C. Clutter, P. L. Wolfe, D. D. Zalesky, M. K. Nielsen, and J. E. Kinder. 1987. Suckling behavior of calves with dams varying in milk production. J. Anim. Sci. 65:1207-1212.

de Passillé, A. M. 2001. Sucking motivation and related problems in calves. Appl. Anim. Behav. Sci. 72:175-187.

de Passillé, A. M., T. F. Borderas, and J. Rushen. 2011. Weaning age of calves fed a high milk allowance by automated feeders: Effects on feed, water, and energy intake, behavioral signs of hunger, and weight gains. J. Dairy Sci. 94:1401-1408.

de Passillé, A. M., B. C. Sweeney, and J. Rushen. 2010. Cross-sucking and gradual weaning of dairy calves. Appl. Anim. Behav. Sci. 124:11-15. de Paula Vieira, A., A. M. de Passilé, and D. M. Weary. 2012a. Effects of the early social environment on the behavioural responses of dairy calves to novel events. J. Dairy Sci. 95:5149-5155.

de Paula Vieira, A., V. Guesdon, A. M. de Passillé, M. A. G. von Keyserlingk, and D. M. Weary. 2008. Behavioural indicators of hunger in dairy calves. Appl. Anim. Behav. Sci. 109:180-189.

de Paula Vieira, A., M. A. G. von Keyserlingk, and D. M. Weary. 2010. Effects of pair versus single housing on performance and behavior of dairy calves before and after weaning from milk. J. Dairy Sci. 93:3079-3085.

de Paula Vieira, A., M. A. G. von Keyserlingk, and D. M. Weary. 2012b. Presence of an older weaned companion influences feeding behavior and improves performance of dairy calves before and after weaning from milk. J. Dairy Sci. 95:3218-3224.

Duve, L. R., and M. B. Jensen. 2011. The level of social contact affects social behaviour in pre-weaned dairy calves. Appl. Anim. Behav. Sci. 135:34-43.

Duve, L. R., and M. B. Jensen. 2012. Social behavior of young dairy calves housed with limited or full social contact with a peer. J. Dairy Sci. 95:5936-5945.

Duve, L. R., D. M. Weary, U. Halekoh, and M. B. Jensen. 2012. The effects of social contact and milk allowance on responses to handling, play, and social behavior in young dairy calves. J. Dairy Sci. 95:6571-6581.

Færevik, G., I. L. Andersen, M. B. Jensen, and K. E. Bøe. 2007. Increased group size reduces conflicts and strengthens the preference for familiar group mates in dairy calves (Bos taurus). Appl. Anim. Behav. Sci. 108:215-228.

Færevik, G., M. B. Jensen, and K. E. Bøe. 2006. Dairy calves social preferences and the significance of a companion animal during separation from the group. Appl. Anim. Behav. Sci. 99:205-221.

Færevik, G., M. B. Jensen, and K. E. Bøe. 2010. The effect of group composition and age on social behavior and competition in groups of weaned dairy calves. J. Dairy Sci. 93:4274-4279.

Fahlke, C., J. G. Lorenz, J. Long, M. Champoux, S. J. Suomi, and J. D. Higley. 2000. Rearing experiences and stress-induced plasma coritsol as early risk factors for excessive alcohol consumption in nonhuman primates. Alcohol. Clin. Exp. Res. 24:644-650.

Fone, K. C., and M. V. Porkess. 2008. Behavioural and neurochemical effects of post-weaning social isolation in rodents-relevance to developmental neuropsychiatric disorders. Neurosci. Biobehav. Rev. 32:1087-1102.

Fowler, C. D., Y. Liu, C. Ouimet, and Z. Wang. 2002. The effects of social environment on adult neurogenesis in the female prairie vole. J. Neurobiol. 51:115-128.

Freeland, J. W., and D. H. Janzen. 1974. Strategies in herbivory by mammals: The role of plant secondary compounds. Am. Nat. 108:269-289.

Gaillard, C., R. K. Meagher, M. A. G. von Keyserlingk, and D. M. Weary. 2014. Social housing improves dairy calves' performance in two cognitive tests. PLoS ONE 9:e90205.

Galef, B. G. 1981. Development of olfactory control of feeding-site selection in rat pups. J. Comp. Physiol. Psychol. 95:615-622.

Galef, B. G., and K. N. Laland. 2005. Social learning in animals: Empirical studies and theoretical models. Bioscience 55:489-499.

Galef, B. J. 1988. Communication of information concerning distant diets in a social, central-place foraging species: Rattus norvegicus. Pages 119-139 in Social Learning: Psychological and Biological Perspectives. Erlbaum ed., Hillsdale, NJ.

Gottman, J. M. 1977. Toward a definition of social isolation in children. Child Dev. 48:513-517.

Gulliksen, S. M., K. Lie, T. Loken, and O. Osteras. 2009. Calf mortality in Norwegian dairy herds. J. Dairy Sci. 92:2782-2795.

Hall, F. S. 1998. Social deprivation of neonatal, adolescent, and adult rats has distinct neurochemical and behavioral consequences. Crit. Rev. Neurobiol. 12:129-162.

Haller, J., G. Harold, C. Sandi, and I. D. Neumann. 2014. Effects of adverse early-life events on aggression and anti-social behaviours in animals and humans. J. Neuroendocrinol. 26:724-738. 
Hanekamp, W. J. A., A. C. Smits, and H. K. Wierenga. 1994. Open versus closed barn and individual versus group-housing for bull calves destined for beef production. Livest. Prod. Sci. 37:261-270.

Hänninen, L., A. M. De Passillé, and J. Rushen. 2005. The effect of flooring type and social grouping on the rest and growth of dairy calves. Appl. Anim. Behav. Sci. 91:193-204.

Hänninen, L., H. Hepola, J. Rushen, A. M. de Passillé, P. Pursiainen, V. M. Tuure, L. Syrjälä-Qvist, M. Pyykkönen, and H. Saloniemi. 2003. Resting behaviour, growth and diarrhoea incidence rate of young dairy calves housed individually or in groups in warm or cold buildings. Acta Agric. Scand. A Anim. Sci. 53:21-28.

Harlow, H. F., R. O. Dodsworth, and M. K. Harlow. 1965. Total social isolation in monkeys. Proc. Natl. Acad. Sci. USA 54:90-97.

Heim, C., and C. B. Nemeroff. 2001. The role of childhood trauma in the neurobiology of mood and anxiety disorders: preclinical and clinical studies. Biol. Psychiatry 49:1023-1039.

Heim, C., P. M. Plotsky, and C. B. Nemeroff. 2004. Importance of studying the contributions of early adverse experience to neurobiological findings in depression. Neuropsychopharmacology 29:641648.

Hennessy, M. B., S. Kaiser, and N. Sachser. 2009. Social buffering of the stress response: diversity, mechanisms, and functions. Front. Neuroendocrinol. 30:470-482.

Hennessy, M. B., D. S. Maken, and F. C. Graves. 2000. Consequences of the presence of the mother or unfamiliar adult female on cortisol, ACTH, testosterone and behavioral responses of periadolescent guinea pigs during exposure to novelty. Psychoneuroendocrinology 25:619-632.

Hepola, H., L. Hänninen, P. Pursiainen, V. M. Tuure, L. Syrjälä-Qvist, M. Pyykkönen, and H. Saloniemi. 2006. Feed intake and oral behaviour of dairy calves housed individually or in groups in warm or cold buildings. Livest. Sci. 105:94-104.

Herrmann, J., and U. Knierim. 1999. Auswirkungen der Tränketechnik auf das Sozialverhalten zwei bis acht Wochen alter Mastkälber in Gruppenhaltung (Effects of different feeding techniques on the social behaviour from two to eight weeks old veal calves in group housing). Aktuelle Arbeiten zur artgemässen Tierhaltung 382:130-136.

Higley, J. D., M. F. Hasert, S. J. Suomi, and M. Linnoila. 1991. Nonhuman primate model of alcohol abuse: Effects of early experience, personality, and stress on alcohol consumption. Proc. Natl. Acad. Sci. USA 88:7261-7265.

Holm, L., M. B. Jensen, and L. L. Jeppesen. 2002. Calves' motivation for access to two different types of social contact measured by operant conditioning. Appl. Anim. Behav. Sci. 79:175-194.

Holson, R. R., A. C. Scallet, S. F. Ali, and B. B. Turner. 1991. Isolation stress revisited: Isolation-rearing effects depend on animal care methods. Physiol. Behav. 49:1107-1118.

Hötzel, M. J., C. Longo, L. F. Balcão, C. S. Cardoso, and J. H. C. Costa. 2014. A survey of management practices that influence performance and welfare of dairy calves reared in Southern Brazil. PLoS ONE 9:e114995.

House, J. S., K. R. Landis, and D. Umberson. 1988. Social relationships and health. Science 241:540-545.

Hur, T. Y., Y. H. Jung, C. Y. Choe, Y. I. Cho, S. J. Kang, H. J. Lee, K. S. Ki, K. S. Baek, and G. H. Suh. 2013. The dairy calf mortality: The causes of calf death during ten years at a large dairy farm in Korea. Korean J. Vet. Res. 53:103-108.

Jensen, M. B. 2003. The effects of feeding method, milk allowance and social factors on milk feeding behaviour and cross-sucking in group housed dairy calves. Appl. Anim. Behav. Sci. 80:191-206.

Jensen, M. B. 2004. Computer-controlled milk feeding of dairy calves: The effects of number of calves per feeder and number of milk portions on use of feeder and social behavior. J. Dairy Sci. 87:34283438 .

Jensen, M. B. 2009. Short communication: Milk meal pattern of dairy calves is affected by computer-controlled milk feeder set-up. J. Dairy Sci. 92:2906-2910.

Jensen, M. B., A. M. de Passillé, M. A. G. von Keyserlingk, and J. Rushen. 2008. A barrier can reduce competition over teats in pairhoused milk-fed calves. J. Dairy Sci. 91:1607-1613.
Jensen, M. B., L. R. Duve, and D. M. Weary. 2015. Pair housing and enhanced milk allowance increase play behavior and improve performance in dairy calves. J. Dairy Sci. 98:2568-2575.

Jensen, M. B., and L. E. Larsen. 2014. Effects of level of social contact on dairy calf behavior and health. J. Dairy Sci. 97:5035-5044.

Jensen, M. B., K. S. Vestergaard, C. C. Krohn, and L. Munksgaard 1997. Effect of single versus group housing and space allowance on responses of calves during open-field tests. Appl. Anim. Behav. Sci. 54:109-121.

Johnson, K., C. C. Burn, and D. C. Wathes. 2011. Rates and risk factors for contagious disease and mortality in young dairy heifers. Anim. Sci. Rev. 205:101-113.

Jones, G. H., C. A. Marsden, and T. W. Robbins. 1991. Behavioural rigidity and rule-learning deficits following isolation-rearing in the rat: Neurochemical correlates. Behav. Brain Res. 43:35-50.

Kanitz, E., B. Puppe, M. Tuchscherer, M. Heberer, T. Viergutz, and A. Tuchscherer. 2009. A single exposure to social isolation in domestic piglets activates behavioural arousal, neuroendocrine stress hormones, and stress-related gene expression in the brain. Physiol. Behav. 98:176-185.

Keeling, L. J., and J. F. Hurnik. 1996. Social facilitation and synchronization of eating between familiar and unfamiliar newly weaned piglets. Acta Agric. Scand. A Anim. Sci. 46:54-60.

Keil, N. M., and W. Langhans. 2001. The development of intersucking in dairy calves around weaning. Appl. Anim. Behav. Sci. 72:295308.

Kercmar, J., S. A. Tobet, and G. Majdic. 2014. Social isolation during puberty affects female sexual behavior in mice. Front. Behav. Neurosci. 8:337.

Key, C., and R. M. MacIver. 1980. The effects of maternal influences on sheep: Breed differences in grazing, resting and courtship behaviour. Appl. Anim. Behav. Sci. 6:33-48.

Kikusui, T., J. T. Winslow, and Y. Mori. 2006. Social buffering: relief from stress and anxiety. Philos. Trans. R. Soc. Lond. B Biol. Sci. 361:2215-2228.

Kiyokawa, Y., S. Hiroshima, Y. Takeuchi, and Y. Mori. 2014a. Social buffering reduces male rats' behavioral and corticosterone responses to a conditioned stimulus. Horm. Behav. 65:114-118.

Kiyokawa, Y., A. Honda, Y. Takeuchi, and Y. Mori. 2014b. A familiar conspecific is more effective than an unfamiliar conspecific for social buffering of conditioned fear responses in male rats. Behav. Brain Res. 267:189-193.

Kraemer, G. W., M. H. Ebert, D. E. Schmidt, and W. T. McKinney. 1991. Strangers in a strange land: A psychobiological study of mother-infant separation in rhesus monkeys. Child Dev. 62:548 566.

Krohn, C. C., J. Foldager, and L. Mogensen. 1999. Long-term effect of colostrum feeding methods on behaviour in female dairy calves. Acta Agric. Scand. A Anim. Sci. 49:57-64.

Kuller, W. I., T. J. Tobias, and A. van Nes. 2010. Creep feed intake in unweaned piglets is increased by exploration stimulating feeder. Livest. Prod. Sci. 129:228-231.

Kung, L., S. Demarco, L. N. Siebenson, E. Joyner, G. F. W. Haenlein, and R. M. Morris. 1997. An evaluation of two management systems for rearing calves fed milk replacer. J. Dairy Sci. 80:2529-2533.

Langbein, J., and M. L. Raasch. 2000. Investigations on the hiding behaviour of calves at pasture. Arch. Anim. Breed. 43:203-210.

Launchbaugh, K. L., and L. D. Howery. 2005. Understanding landscape use patterns of livestock as a consequence of foraging behavior. Rangeland Ecol. Manag. 58:99-108.

Le Neindre, P. 1989a. Influence of cattle rearing conditions and breed on social relationships of mother and young. Appl. Anim. Behav. Sci. 23:117-127.

Le Neindre, P. 1989b. Influence of rearing conditions and breed on social behavior and activity of cattle in novel environments. Appl. Anim. Behav. Sci. 23:129-140.

Lidfors, L., and L. Isberg. 2003. Intersucking in dairy cattle-Review and questionnaire. Appl. Anim. Behav. Sci. 80:207-231.

Lidfors, L., P. Jensen, and B. Algers. 1994. Suckling in free-ranging beef cattle: Temporal patterns of suckling bouts and effects of age and sex. Ethology 98:321-332. 
Lidfors, L. M. 1996. Behavioural effects of separating the dairy calf immediately or 4 days post-partum. Appl. Anim. Behav. Sci. 49:269-283.

Lipkind, D., R. Nottebohm, R. Rado, and A. Barnea. 2002. Social change affects the survival of new neurons in the forebrain of adult songbirds. Behav. Brain Res. 133:31-43.

Losinger, W. C., and A. Heinrichs. 1997. Management practices associated with high mortality among preweaned dairy heifers. J. Dairy Res. 64:1-11.

Losinger, W. C., S. J. Wells, L. P. Garber, and H. S. Hurd. 1995. Management factors related to salmonella shedding by dairy heifers. J. Dairy Sci. 78:2464-2472.

Lovic, V., D. J. Palombo, and A. S. Fleming. 2011. Impulsive rats are less maternal. Dev. Psychobiol. 53:13-22.

Lukas, M., R. Bredewold, R. Landgraf, I. D. Neumann, and A. H. Veenema. 2011. Early life stress impairs social recognition due to a blunted response of vasopressin release within the septum of adult male rats. Psychoneuroendocrinology 36:843-853.

Maatje, K., J. Verhoeff, W. D. J. Kremer, A. L. M. Cruijsen, and T. S. G. A. M. van den Ingh. 1993. Automated feeding of milk replacer and health control of group-housed veal calves. Vet. Rec. 133:266-270.

Margerison, J. K., T. R. Preston, N. Berry, and C. J. C. Phillips. 2003. Cross-sucking and other oral behaviours in calves, and their relation to cow suckling and food provision. Appl. Anim. Behav. Sci. 80:277-286.

Mattiello, S., E. Canali, V. Ferrante, M. Caniatti, F. Gottardo, G. Cozzi, I. Andrighetto, and M. Verga. 2002. The provision of solid feeds to veal calves: II. Behavior, physiology, and abomasal damage. J. Anim. Sci. 80:367-375.

McGuirk, S. M. 2008. Disease management of dairy calves and heifers. Vet. Clin. North Am. Food Anim. Pract. 24:139-153.

Meagher, R. K., R. R. Daros, J. H. C. Costa, M. A. G. von Keyserlingk, M. Hötzel, and D. M. Weary. 2015. Individual housing impairs reversal learning and increases fear of novel objects in dairy calves. PLoS ONE 10:e132828.

Mirza, S. N., and F. D. Provenza. 1992. Effects of age and conditions of exposure on maternally mediated food selection in lambs. Appl. Anim. Behav. Sci. 33:3542-3550.

Mirza, S. N., and F. D. Provenza. 1994. Socially induced food avoidance in lambs: Direct or indirect maternal influence? J. Anim. Sci. 72:899-902.

Moallem, U., D. Werner, H. Lehrer, M. Zachut, L. Livshitz, S. Yakoby, and A. Shamay. 2010. Long-term effects of ad libitum whole milk prior to weaning and prepubertal protein supplementation on skeletal growth rate and first-lactation milk production. J. Dairy Sci. 93:2639-2650.

Moberg, G. P., and V. A. Wood. 1982. Effect of differential rearing on the behavioural and adrenocortical response of lambs to a novel environment. Appl. Anim. Ethol. 8:269-279.

Mohammed, H. O., S. E. Wade, and S. Schaaf. 1999. Risk factors associated with Cryptosporidium parvum infection in dairy cattle in southeastern New York State. Vet. Parasitol. 83:1-13.

Mounier, L., H. Dubroeucq, S. Andanson, and I. Veissier. 2006. Variations in meat $\mathrm{pH}$ of beef bulls in relation to conditions of transfer to slaughter and previous history of the animals. J. Anim. Sci. 84:1567-1576.

Murphey, R. M., and F. A. de Moura Duarte. 1990. Social aggregations in cattle. II. Contributions of familiarity and genetic similarity. Behav. Genet. 20:355-368.

Napolitano, F., G. F. Cifuni, C. Pacelli, A. M. Riviezzi, and A. Girolami. 2002. Effect of artificial rearing on lamb welfare and meat quality. Meat Sci. 60:307-315.

Napolitano, F., G. De Rosa, and A. Sevi. 2008. Welfare implications of artificial rearing and early weaning in sheep. Appl. Anim. Behav. Sci. 110:58-72.

Napolitano, F., V. Marino, G. De Rosa, R. Capparelli, and A. Bordi. 1995. Influence of artificial rearing on behavioural and immune response of lambs. Appl. Anim. Behav. Sci. 45:245-253.
Neigh, G. N., C. F. Gillespie, and C. B. Nemeroff. 2009. The neurobiological toll of child abuse and neglect. Trauma Violence Abuse 10:389-410.

Nicol, C. 2006. How animals learn from each other. Appl. Anim. Behav. Sci. 100:58-63.

Nielsen, P. P., M. B. Jensen, and L. Lidfors. 2008. Milk allowance and weaning method affect the use of a computer controlled milk feeder and the development of cross-sucking in dairy calves. Appl. Anim. Behav. Sci. 109:223-237.

Nolte, D. L., F. D. Provenza, and D. F. Balph. 1990. The establishment and persistence of food preferences in lambs exposed to selected foods. J. Anim. Sci. 68:998-1002.

Ortiz-Pelaez, A., D. G. Pritchard, D. U. Pfeiffer, E. Jones, P. Honeyman, and J. J. Mawdsley. 2008. Calf mortality as a welfare indicator on British cattle farms. Vet. J. 176:177-181.

Parker, K. J., and D. Maestripieri. 2011. Identifying key features of early stressful experiences that produce stress vulnerability and resilience in primates. Neurosci. Biobehav. Rev. 35:1466-1483.

Pedersen, R. E., J. T. Sørensen, F. Skjøth, J. Hindhede, and T. Rousing Nielsen. 2009. How milk-fed dairy calves perform in stable versus dynamic groups. Livest. Sci. 121:215-218.

Pempek, J. A., M. L. Eastridge, N. A. Botheras, C. C. Croney, and W. S. Bowen Yoho. 2013. Effects of alternative housing and feeding systems on the behavior and performance of dairy heifer calves. Prof. Anim. Sci. 29:278-288.

Perez, E., J. P. T. M. Noordhuizen, L. A. Van Wuijkhuise, and E. N. Stassen. 1990. Management factors related to calf morbidity and mortality rates. Livest. Prod. Sci. 25:79-93.

Phillips, C. J. C. 2004. The effects of forage provision and group size on the behavior of calves. J. Dairy Sci. 87:1380-1388.

Piller, C. A. K., J. M. Stookey, and J. M. Watts. 1999. Effects of mirror-image exposure on heart rate and movement of isolated heifers. Appl. Anim. Behav. Sci. 63:93-102.

Poletto, R., J. M. Siegford, J. P. Steibel, P. M. Coussens, and A. J. Zanella. 2006a. Investigation of changes in global gene expression in the frontal cortex of early-weaned and socially isolated piglets using microarray and quantitative real-time RT-PCR. Brain Res. 1068:7-15.

Poletto, R., J. P. Steibel, J. M. Siegford, and A. J. Zanella. 2006b. Effects of early weaning and social isolation on the expression of glucocorticoid and mineralocorticoid receptor and 11ß-hydroxysteroid dehydrogenase 1 and 2 mRNAs in the frontal cortex and hippocampus of piglets. Brain Res. 1067:36-42.

Provenza, F. D., and D. F. Balph. 1987. Diet learning by domestic ruminants: Theory, evidence and practical implications. Appl. Anim. Behav. Sci. 18:211-232.

Provenza, F. D., J. J. Villalba, L. E. Dziba, S. B. Atwood, and R. E. Banner. 2003. Linking herbivore experience, varied diets, and plant biochemical diversity. Small Rumin. Res. 49:257-274.

Quigley, J. D. 1997. Raising replacement heifers from birth to weaning. Pages 21-27 in Proc. 1997 Western Canadian Dairy Seminar, Red Deer, Alberta. University of Alberta, Edmonton, Canada.

Raboisson, D., F. Delor, E. Cahuzac, C. Gendre, P. Sans, and G. Allaire. 2013. Perinatal, neonatal, and rearing period mortality of dairy calves and replacement heifers in France. J. Dairy Sci. 96:2913-2924.

Ralphs, M. H., D. Graham, and L. F. James. 1994. Social facilitation influences cattle to graze locoweed. J. Range Manage. 1994:123126

Rault, J. L. 2012. Friends with benefits: Social support and its relevance for farm animal welfare. Appl. Anim. Behav. Sci. 136:1-14.

Raussi, S., S. Nivskanen, J. Siivonen, L. Hänninen, H. Hepola, L. Jauhiainen, and I. Veissier. 2010. The formation of preferential relationships at early age in cattle. Behav. Processes 84:726-731.

Raussi, S., B. J. Lensink, A. Boissy, M. Pyykkönent, and I. Veissier. 2003. The effect of contact with conspecifics and humans on calves' behaviour and stress responses. Anim. Welf. 12:191-202.

Reimert, I., J. E. Bolhuis, B. Kemp, and T. B. Rodenburg. 2014. Social support in pigs with different coping styles. Physiol. Behav. 129:221-229. 
Reinhardt, V., and A. Reinhardt. 1981. Natural sucking performance and age of weaning in zebu cattle (Bos indicus). J. Agric. Sci. 96:309-312.

Rettie, W. J., and F. Messier. 2001. Range use and movement rates of woodland caribou in Saskatchewan. Can. J. Zool. 79:1933-1940.

Richard, A. L., L. D. Muller, and A. J. Heinrichs. 1988. Feeding acidified milk replacer ad libitum to calves housed in group versus individual pens. J. Dairy Sci. 71:2203-2209.

Rugbjerg, H., E. M. Nielsen, and J. S. Andersen. 2003. Risk factors associated with faecal shedding of verocytotoxin-producing Escherichia coli $\mathrm{O} 157$ in eight known-infected Danish dairy herds. Prev. Vet. Med. 58:101-113.

Rutter, D. R. 1979. The reconstruction of schizophrenic speech. Br. J. Psychiatry 134:356-359.

Sackett, G. P. 1970. Unlearned responses, differential rearing experiences, and the development of social attachments by rhesus monkeys. Pages 111-140 in Primate Behavior: Developments in Field and Laboratory Research. L. A. Rosenblum ed. Academic Press, New York, NY.

Sackett, G. P., G. C. Ruppenthal, C. E. Fahrenbruch, R. A. Holm, and W. T. Greenough. 1981. Social isolation rearing effects in monkeys vary with genotype. Dev. Psychol. 17:313-318.

Sato, S., D. G. M. Wood-Gush, and G. Wetherill. 1987. Observations on creche behaviour in suckler calves. Behav. Processes 15:333-343.

Schrijver, N. C., N. I. Bahr, I. C. Weiss, and H. Würbel. 2002. Dissociable effects of isolation rearing and environmental enrichment on exploration, spatial learning and HPA activity in adult rats. Pharmacol. Biochem. Behav. 73:209-224.

Schrijver, N. C., and H. Würbel. 2001. Early social deprivation disrupts attentional, but not affective, shifts in rats. Behav. Neurosci. 115:437-442.

Serra, M., E. Sanna, M. C. Mostallino, and G. Biggio. 2007. Social isolation stress and neuroactive steroids. Eur. Neuropsychopharmacol. 17:1-11.

Shanks, N., and S. L. Lightman. 2001. The maternal-neonatal neuroimmune interface: Are there long-term implications for inflammatory or stress-related disease? J. Clin. Invest. 108:1567-1573.

Shapiro, L. E., and T. R. Insel. 1990. Infant's response to social separation reflects adult differences in affiliative behavior: A comparative developmental study in prairie and montane voles. Dev. Psychobiol. 23:375-393.

Soberon, F., E. Raffrenato, R. W. Everett, and M. E. Van Amburgh 2012. Preweaning milk replacer intake and effects on long-term productivity of dairy calves. J. Dairy Sci. 95:783-793.

Steenkamer, N. 1982. Alternative housing systems for veal calves, their effect on welfare and performance and their economic feasibility Pages 226-234 in Welfare and Husbandry of Calves: Current Topics in Veterinary Medicine and Animal Science. J. P. Signoret, ed. Springer, Hingham, MA.

Stull, C., and J. Reynolds. 2008. Calf welfare. Vet. Clin. North Am. Food Anim. Pract. 24:191-203

Suomi, S. J. 1991. Early stress and adult emotional reactivity in rhesus monkeys. Ciba Found. Symp. 156:171-183.

Suomi, S. J., H. F. Harlow, and S. D. Kimball. 1971. Behavioral effects of prolonged partial social isolation in the rhesus monkey. Psychol. Rep. 29:1171-1177.

Svensson, C., and P. Liberg. 2006. The effect of group size on health and growth rate of Swedish dairy calves housed in pens with automatic milk-feeders. Prev. Vet. Med. 73:43-53.

Svensson, C., K. Lundborg, U. Emanuelson, and S. Olsson. 2003. Morbidity in Swedish dairy calves from birth to 90 days of age and individual calf-level risk factors for infectious diseases. Prev. Vet. Med. 58:179-197.

Tapki, I. 2007. Effects of individual or combined housing systems on behavioural and growth responses of dairy calves. Acta Agric. Scand. A Anim. Sci. 57:55-60.

Terré, M., A. Bach, and M. Devant. 2006. Performance and behaviour of calves reared in groups or individually following an enhancedgrowth feeding programme. J. Dairy Res. 73:480-486.
Thorsteinsson, E. B., J. E. James, and M. E. Gregg. 1998. Effects of video-relayed social support on hemodynamic reactivity and salivary cortisol during laboratory-based behavioral challenge. Health Psychol. 17:436-444.

Toth, M., E. Mikics, A. Tulogdi, M. Aliczki, and J. Haller. 2011. Postweaning social isolation induces abnormal forms of aggression in conjunction with increased glucocorticoid and autonomic stress responses. Horm. Behav. 60:28-36.

Troller-Renfree, S., J. M. McDermott, C. A. Nelson, C. H. Zeanah, and N. A. Fox. 2015. The effects of early foster care intervention on attention biases in previously institutionalized children in Romania. Dev. Sci. 18:713-722.

Tuchscherer, M., E. Kanitz, B. Puppe, and A. Tuchscherer. 2006. Early social isolation alters behavioral and physiological responses to an endotoxin challenge in piglets. Horm. Behav. 50:753-761.

USDA. 2008. Dairy 2007, Part III: Reference of Dairy Cattle Health and Management Practices in the United States. USDA, National Animal Health Monitoring System, Fort Collins, CO.

Valzelli, L. 1973. The "isolation syndrome" in mice. Psychopharmacologia 31:305-320.

Van Putten, G. 1982. Welfare in veal calf units. Vet. Rec. 111:437-440

Vasseur, E., F. Borderas, R. I. Cue, D. Lefebvre, D. Pellerin, J. Rushen, K. M. Wade, and A. M. de Passillé. 2010. A survey of dairy calf management practices in Canada that affect animal welfare. J. Dairy Sci. 93:1307-1315.

Veenema, A. H., A. Blume, D. Niederle, B. Buwalda, and I. D. Neumann. 2006. Effects of early life stress on adult male aggression and hypothalamic vasopressin and serotonin. Eur. J. Neurosci. 24:1711-1720.

Veenema, A. H., R. Bredewold, and I. D. Neumann. 2007. Opposite effects of maternal separation on intermale and maternal aggression in C57BL/6 mice: Link to hypothalamic vasopressin and oxytocin immunoreactivity. Psychoneuroendocrinology 32:437-450.

Veissier, I., P. Chazal, P. Pradel, and P. Le Neindre. 1997. Providing social contacts and objects for nibbling moderates reactivity and oral behaviors in veal calves. J. Anim. Sci. 75:356-365.

Veissier, I., A. M. De Passille, G. Després, J. Rushen, I. Charpentier, A. R. Ramirez De La Fe, and P. Pradel. 2002. Does nutritive and non-nutritive sucking reduce other oral behaviors and stimulate rest in calves? J. Anim. Sci. 80:2574-2587.

Veissier, I., V. Gesmier, P. Le Neindre, J. Y. Gautier, and G. Bertrand. 1994. The effects of rearing in individual crates on subsequent social behaviour of veal calves. Appl. Anim. Behav. Sci. 41:199-210.

Ventura, B. A., M. A. G. von Keyserlingk, C. A. Schuppli, and D. M. Weary. 2013. Views on contentious practices in dairy farming: The case of early cow-calf separation. J. Dairy Sci. 96:6105-6116.

Vitale, A. F., M. Tennucci, M. Papini, and S. Lovari. 1986. Social behaviour of the calves of semi-wild aremma cattle, Bos primigenius taurus. Appl. Anim. Behav. Sci. 16:217-231.

von Keyserlingk, M. A. G., L. Brusius, and D. M. Weary. 2004. Competition for teats and feeding behavior by group-housed dairy calves. J. Dairy Sci. 87:4190-4194.

von Keyserlingk, M. A. G., and D. M. Weary. 2007. Maternal behavior in cattle. Horm. Behav. 52:106-113.

Wagner, K., D. Seitner, K. Barth, R. Palme, A. Futschik, and S. Waiblinger. 2012. Integration into the dairy cow herd: Long-term effects of mother contact during the first twelve weeks of life. Appl. Anim. Behav. Sci. 141:117-129.

Wagner, K., D. Seitner, K. Barth, R. Palme, A. Futschik, and S. Waiblinger. 2014. Effects of mother versus artificial rearing during the first 12 weeks of life on challenge responses of dairy cows. Appl. Anim. Behav. Sci. 164:1-11.

Walker, W. L., W. B. Epperson, T. E. Wittum, L. K. Lord, P. J. Rajala-Schultz, and J. Lakritz. 2012. Characteristics of dairy calf ranches: Morbidity, mortality, antibiotic use practices, and biosecurity and biocontainment practices. J. Dairy Sci. 95:2204-2214.

Waltner-Toews, D., S. W. Martin, and A. H. Meek. 1986a. Dairy calf management morbidity and mortality in Ontario Holstein herds. I: The data. Prev. Vet. Med. 4:103-124. 
Waltner-Toews, D., S. W. Martin, and A. H. Meek. 1986b. Dairy calf management, morbidity and mortality in Ontario Holstein herds. III. Association of management with morbidity. Prev. Vet. Med. 4:137-158.

Warnick, V. D., C. W. Arave, and C. H. Mickelsen. 1977. Effects of group, individual, and isolated rearing of calves on weight gain and behavior. J. Dairy Sci. 60:947-953.

Weary, D. M., J. M. Huzzey, and M. A. G. von Keyserlingk. 2009. Board-invited review: Using behavior to predict and identify ill health in animals. J. Anim. Sci. 87:770-777.

Webster, A. J. F., C. Saville, B. M. Church, A. Gnanasakthy, and R. Moss. 1985. Some effects of different rearing systems on health, cleanliness and injury in calves. Br. Vet. J. 141:472-483.
Whiten, A., and A. Mesoudi. 2008. Establishing an experimental science of culture: Animal social diffusion experiments. Phil. Trans. R. Soc. Lond. B Biol. Sci. 363:3477-3488.

Wierup, M. 2000. The control of microbial diseases in animals: Alternatives to the use of antibiotics. Int. J. Antimicrob. Agents 14:315-319.

Worobec, E. K., I. J. H. Duncan, and T. M. Widowski. 1999. The effects of weaning at 7,14 and 28 days on piglet behaviour. Appl Anim. Behav. Sci. 62:173-182.

Xiccato, G., A. Trocino, P. I. Queaque, A. Sartori, and A. Carazzolo. 2002. Rearing veal calves with respect to animal welfare: Effects of group housing and solid feed supplementation on growth performance and meat quality. Livest. Prod. Sci. 75:269-280. 